\title{
On the enzymes' actions of entomopathogenic fungi against certain indigenous and invasive insect pests
}

\author{
A. M. Moharram ${ }^{1}$, F. A. Abdel-Galil ${ }^{2}$ and W. M. M. Hafez ${ }^{1 *}$
}

\begin{abstract}
Background: Pathogenicity of entomopathogenic fungi (EPF) depends mainly on their ability to produce efficient enzymes, which degrade insect's integument and other cellular components. Lipases are the first enzymes secreted by these fungi, then proteases, phospholipases, and chitinases.

Results: Twenty-six fungal strains, isolated from the aphids, Aphis sp., Linnaeus (Homoptera, Aphididae), the tomato leaf minor, Liriomyza trifolii, Burgess (Diptera, Agromyzidae) (indigenous insects), the red palm weevil, Rhynchophorus ferrugineus, Olivier (Coleoptera, Curculionidae), and the peach fruit fly, Bactrocera zonata, Saunders (Diptera, Tephritidae) (invasive insects) were tested for their enzymatic activities. Results showed that the majority of these strains were able to produce lipolytic enzymes with the most active being Aspergillus niger, Botryotrichum atrogriseum, Cochliobolus spicifer, Fusarium chlamydosporum, and F. proliferatum. Phospholipase was successfully produced by $73.1 \%$ of the tested strains among which Aspergillus flavus, A. niger, Mucor racemosus, Pochonia chlamydosporia var. catenulata, and Scopulariopsis brevicaulis were the highest producers. Proteolytic enzymes were detected in cultures of all the fungal strains except Aspergillus chevalieri and M. racemosus. The best proteolytic strain was $S$. brevicaulis followed by A. flavus, A. sydowii, and F. semitectum. The chitinolytic ability of the fungal strains was generally weak and the relatively active species belonged to A. flavus, A. niger, B. atrogriseum, $F$. chlamydosporum, F. solani, S. brevicaulis, and Nigrospora oryzae. Quantitative determination of chitinase revealed that the enzyme concentration ranged from 3.478 to $6.44 \mathrm{IU} / \mathrm{ml}$.
\end{abstract}

Conclusion: Most of the isolated fungi had enzymatic activities, but A. niger, F. semitectum, F. solani, F. chlamydosporum, P. chlamydosporia var. catenulata, and S. brevicaulis, were the most active ones.

Keywords: Entomopathogenic fungi, Pathogenicity, Enzymes, Production, Insect pests

\section{Background}

The common insect pest species can be classified into two groups (indigenous and invasive species). Aphids (Aphis spp., Linnaeus) (Homoptera: Aphididae) and the tomato leaf miner (TLM) (Liriomyza trifolii, Burgess) (Diptera, Agromyzidae) are examples of the indigenous insects, whereas the red palm weevil (RPW) (Rhynchophorus ferrugineus, Olivier) (Coleoptera: Curculionidae) and the

\footnotetext{
*Correspondence: walaamamdouh70@yahoo.com

'Department of Botany and Microbiology, Faculty of Science, Assiut University, Assiut, Egypt

Full list of author information is available at the end of the article
}

peach fruit fly (PFF) (Bactrocera zonata, Saunders) (Diptera: Tephritidae) are considered invasive insect pests in Egypt. Aphids cause economic losses by direct feedings, the transport of plant viruses and toxins.

Tomato is one of the major economic host plants of the tomato leaf miner (L. trifolii) which attacks its leaves, buds, stems, and fruits. The insect also attacks other members of the family Solanaceae such as potato and eggplant.

Rhynchophorus ferrugineus is an invasive species that is originated from Southeast Asia, invaded Middle East and several countries of the Mediterranean Basin during

\section{Springer Open}

(c) The Author(s). 2021 Open Access This article is licensed under a Creative Commons Attribution 4.0 International License, which permits use, sharing, adaptation, distribution and reproduction in any medium or format, as long as you give appropriate credit to the original author(s) and the source, provide a link to the Creative Commons licence, and indicate if changes were made. The images or other third party material in this article are included in the article's Creative Commons licence, unless indicated otherwise in a credit line to the material. If material is not included in the article's Creative Commons licence and your intended use is not permitted by statutory regulation or exceeds the permitted use, you will need to obtain permission directly from the copyright holder. To view a copy of this licence, visit http://creativecommons.org/licenses/by/4.0/. 
the last decades. The pest palm trees (El-Mergawy and Al-Ajlan 2011) can completely destroy the palm trees displaying a total loss of foliage and rotting of the trunk (Abelardo et al. 2010).

In Egypt 1995, the peach fruit fly (B.zonata) was recorded attacking a broad range of fruits but it was misidentified as Bactrocera pallidus (Aboul-Ela et al. 1998). Its identification was corrected as $B$. zonata and it was reported as a serious pest on many fruit crops attacking more than 50 host plants (El-Minshawy et al. 1999).

Most of the insects present a segmented cylindrical structure. The integument rigidity is caused by the three layers which form cuticle, epidermis, and basal membrane. The cuticle serves as a physical block against parasitoids and diseases. It is a structure formed by crystalline chitin nanofibers inside proteins, polyphenols, and lipids matrix. Its main component is chitin, a polysaccaride that is like cellulose. Epicuticle is the external layer of the insect's cuticle, waterproof, and acts as the first barrier against microbial attack. It is formed by heterogeneous mix of lipids, long chain alkenes, esters, and fatty acids. The importance of lipases in order to hydrolyze the ester bounds of lipoproteins, fats, and waxes at the interior of the insect integument is well known (Ali et al. 2009). They significantly confer the cuticle penetration and initial nutrients liberate.

Entomopathogenic fungi (EPF) are an important biological control agent of insects. More than 700 fungal species belonging to approximately 90 genera have been reported to infect living insects and kill them but few are involved in the biological control. The pathogenic ability of the fungus depends on the enzymatic equipment which comprises lipases, proteases, and chitinases (Sánchez-Pérez et al. 2014). Once the insect exoskeleton breaks down, the fungus produces great quantities of proteases, which degrade the proteinaceous material found in the epicuticle. The solubilized proteins are degraded releasing amino acids which serve as nutrients for the EPF (Wang et al. 2002). Phospholipases are enzymes responsible for degrading phospholipids of insect's cuticle. Fungal chitinases act synergistically with proteases in order to degrade the insect's cuticle. These enzymes are important virulence factors for the EPF. According to Kaur and Padmaja (2009), there is a certain correlation between the degree of pathogenicity and levels of enzymes that can be used to cause cuticular structure weakening. Establishing a relationship between the active secretion of hydrolytic enzymes and the virulence of EPF is very important in exploring and developing screening methods for identifying new isolates with increased virulence and also for the development of bioproducts based on them (Montesinos-Matías et al. 2011). The present work was conducted to determine the ability of 26 fungal strains isolated from indigenous and invasive insects to produce the 4 types of hydrolytic enzymes including lipases, phospholipases, proteases, and chitinases.

\section{Methods \\ Collection of insect samples}

Eighty-five samples of targeted insect species were collected during the period from 2015 to 2017. Five different localities in Minia Governorate, Egypt, were chosen for insect sampling. These were Deir Mawas, Mallawi, Abu-Qurqas, Minia City, and Samalott. Samples were placed in polyethylene bags and transferred to the laboratory for identification as well as for mycological analysis. Identification of insect species was confirmed by specialists. Samples were included (70 aphids' samples) (4 immature stages of TLM), (6 mature and immature stages of RPW), and (5 immature stages of PFF).

\section{Mycological analysis of insect samples}

Insect samples were placed in sterile Petri dishes containing water soaked sterile filter paper to keep enough humidity for growth of the fungi associated with insects. The growing fungi were then cultured on Sabouraud's dextrose agar (SDA) at $28{ }^{\circ} \mathrm{C}$ for 7-10 days. Fungi were identified according to their phenotypic characters as described by Domsch et al. (2007), Bensch et al. (2012), and Ismail et al. (2015).

The identified fungal strains were preserved as slant cultures on SDA medium. For long-term preservation fungi were placed in $2 \mathrm{ml}$ sterile vials containing $15 \%$ autoclaved glycerol water and kept under ultrafreezing at $-70{ }^{\circ} \mathrm{C}$.

\section{Screening for production of fungal enzymes Lipase production}

Twenty-six fungal strains were tested using the agar medium described by Ulman and Blasins (1974). The medium contained (g/l) peptone, $10 ; \mathrm{MgSO}_{4} \cdot 7 \mathrm{H}_{2} \mathrm{O}, 0.2$; $\mathrm{CaCl}_{2} \cdot 2 \mathrm{H}_{2} \mathrm{O}, 0.2$; Tween $80,10 \mathrm{ml}$; and agar, 15). Tween 80 was autoclaved separately and added to the sterile and cooled basal medium prior to solidification. The medium was dispensed aseptically into $20 \mathrm{ml}$ test tubes (10 $\mathrm{ml}$ each). The tubes were individually inoculated by $50 \mu \mathrm{l}$ of fungal spore suspension and incubated at $28{ }^{\circ} \mathrm{C}$ for 15 days. The lipolytic ability was observed as a visible precipitate due to the formation of crystals of calcium salt of the oleic acid liberated by the enzyme. The depth of each visible precipitate (in $\mathrm{mm}$ ) was measured.

\section{Phospholipase production}

The fungal strains were grown on egg yolk agaras described by Samaranayake et al. (2005). The medium consisted of $(\mathrm{g} / \mathrm{l}) ; 13 \mathrm{~g}$ powdered Sabouraud dextrose agar (SDA), $11.7 \mathrm{~g} \mathrm{NaCl}, 0.12 \mathrm{~g} \mathrm{CaCl} 2$, and egg yolk (10\% in 
Table 1 Incidence of fungal species isolated from the tested insects

\begin{tabular}{|c|c|c|c|c|c|c|}
\hline Fungal species & $\begin{array}{l}\text { Aphids } \\
(N=70)\end{array}$ & $\begin{array}{l}\text { Tomato leaf miner } \\
(N=4)\end{array}$ & $\begin{array}{l}\text { Red palm weevil } \\
(N=6)\end{array}$ & $\begin{array}{l}\text { Peach fruit fly } \\
(N=5)\end{array}$ & $\begin{array}{l}\text { Total } \\
(N=85)\end{array}$ & $\%$ Incidence \\
\hline Alternaria alternata & 7 & 0 & 0 & 2 & 9 & 10.6 \\
\hline A. tenuissima & 13 & 3 & 0 & 2 & 19 & 22.4 \\
\hline Aspergillus chevalieri & 1 & 0 & 0 & 0 & 1 & 1.2 \\
\hline A. flavus & 4 & 1 & 4 & 3 & 12 & 14.1 \\
\hline A. niger & 26 & 2 & 1 & 3 & 32 & 37.7 \\
\hline A. rugulosus & 1 & 0 & 0 & 0 & 1 & 1.2 \\
\hline A. sydowii & 5 & 0 & 0 & 2 & 7 & 8.2 \\
\hline A. terreus & 3 & 0 & 0 & 0 & 3 & 3.5 \\
\hline Botryotrichum atrogriseum & 3 & 0 & 0 & 0 & 3 & 3.5 \\
\hline Cochliobolus spicifer & 1 & 0 & 0 & 0 & 1 & 1.2 \\
\hline Epicoccum nigrum & 2 & 0 & 0 & 0 & 2 & 2.4 \\
\hline Fusarium chlamydosporum & 12 & 0 & 0 & 0 & 12 & 14.1 \\
\hline Fusarium proliferatum & 12 & 0 & 2 & 0 & 14 & 16.5 \\
\hline F. semitectum & 2 & 0 & 0 & 0 & 2 & 2.4 \\
\hline F. solani & 11 & 0 & 1 & 0 & 12 & 14.1 \\
\hline F. subglutinans & 0 & 0 & 1 & 0 & 1 & 1.2 \\
\hline F. verticillioides & 1 & 0 & 0 & 2 & 3 & 3.5 \\
\hline Mucor racemosus & 13 & 1 & 0 & 1 & 14 & 16.5 \\
\hline Nigrospora oryzae & 0 & 0 & 0 & 1 & 1 & 1.2 \\
\hline Penicillium aurantiogriseum & 1 & 0 & 0 & 0 & 1 & 1.2 \\
\hline P. oxalicum & 0 & 0 & 0 & 1 & 1 & 1.2 \\
\hline Pochonia chlamydosporia var. catenulata & 0 & 0 & 0 & 1 & 1 & 1.2 \\
\hline Scopulariopsis brevicaulis & 14 & 0 & 1 & 0 & 14 & 16.5 \\
\hline Talaromyces pinophilum & 0 & 0 & 1 & 0 & 1 & 1.2 \\
\hline Toxicocladosporium irritans & 16 & 0 & 0 & 0 & 16 & 18.8 \\
\hline Verticillium sp. & 7 & 0 & 1 & 0 & 8 & 9.4 \\
\hline Total no. of species & 21 & 4 & 8 & 10 & 26 & \\
\hline
\end{tabular}

sterile $0.85 \%$ saline water). The egg yolk was centrifuged at $500 \mathrm{~g}$ for $10 \mathrm{~min}$ at room temperature, and $80 \mathrm{ml}$ of the supernatant was mixed with the liquefied sterilized medium. The medium was then distributed into $20 \mathrm{ml}$ sterile test tubes $(10 \mathrm{ml} /$ tube). After solidification, the test fungi were inoculated $(50 \mu \mathrm{l}$ of fungal spore suspension) and the cultures were incubated at $25{ }^{\circ} \mathrm{C}$ for 14 days. Extracellular phospholipase activity was detected by measuring the depth of precipitation zone below the fungal colony.

\section{Protease production}

Proteolytic activity of the fungal strains was detected using casein hydrolysis medium described by Paterson and Bridge (1994). The medium had the composition of $(\mathrm{g} / \mathrm{l}): \quad \mathrm{KH}_{2} \mathrm{PO}_{4}, \quad 1.0 ; \quad \mathrm{KCL}, \quad 0.5 ; \quad \mathrm{MgSO}_{4} 7 \mathrm{H}_{2} \mathrm{O}, \quad 0.2 ;$ $\mathrm{CaCl}_{2} \cdot 2 \mathrm{H}_{2} \mathrm{O}$, 0.1; glucose, 10, agar, 15, and distilled water to $1 \mathrm{~L}$ ). After autoclaving at $121{ }^{\circ} \mathrm{C}$ for $20 \mathrm{~min}, 25$ $\mathrm{ml}$ of $15 \%$ sterilized skimmed milk was added and the medium was distributed into $20 \mathrm{ml}$ capacity test tubes $(10 \mathrm{ml}$ each). Each tube was inoculated by $50 \mu \mathrm{l}$ of fungal spore suspension and incubated at $28{ }^{\circ} \mathrm{C}$ for 17 days. Proteolysis was observed as degradation of milk protein appeared as clear depth in the tube. The depth of clear zone below the fungal colony was measured (in $\mathrm{mm}$ ) as indication of casein hydrolysis by fungi.

\section{Chitinase production}

The isolated fungal strains were screened for chitinase activity on chitin-agar medium (Jenin et al. 2016). The medium consisted of (g/l): $(\mathrm{NH} 4)_{2} \mathrm{SO}_{4}(1 \mathrm{~g}), \mathrm{K}_{2} \mathrm{HPO}_{4}(1$ g), $\mathrm{KCl}(0.5 \mathrm{~g}), \mathrm{NaCl}(5 \mathrm{~g}), \mathrm{MgSO}_{4}(0.5 \mathrm{~g}), \mathrm{FeSO}_{4}(0.01$ g), agar agar $(20 \mathrm{~g})$, and colloidal chitin $(5 \mathrm{~g})$. A portion of isolated fungus inoculated on chitin agar tubes, 
incubated at room temperature for 14 days. The chitinase activity was observed by the halo zone of clearances below the fungal colonies.

\section{Quantitative estimation of chitinase activity}

Five fungal strains, which showed a good chitinase activity, were selected for this part of study. These fungi were individually grown in $250 \mathrm{ml}$ capacity flasks each contained $100 \mathrm{ml}$ autoclaved liquid medium of the following composition $(\mathrm{g} / \mathrm{l}): 0.5 \mathrm{~g}$ of $\mathrm{NaCl}, 0.5 \mathrm{~g}$ of $\mathrm{CaCl} 2,3 \mathrm{~g}$ of $\mathrm{KH} 2 \mathrm{PO} 4,1 \mathrm{~g}$ of K2HPO4, $0.7 \mathrm{~g}$ of $\mathrm{MgSO} 4.7 \mathrm{H} 2 \mathrm{O}, 1.4 \mathrm{~g}$ of $(\mathrm{NH} 4)_{2} \mathrm{SO} 4$, and $5 \mathrm{~g}$ of colloidal chitin, $\mathrm{pH}$ was adjusted to 4.7. Culture filtrates were harvested after 14 days and the enzyme assay was performed. As described by Jha and Modi (2017) chitinase activity was determined by mixing $0.9 \mathrm{ml}$ of $1 \%$ chitin, prepared in 50 $\mathrm{mM} \mathrm{Na-citrate}$ buffer ( $\mathrm{PH} 5.4$ ) with $1 \mathrm{ml}$ of filtered crude enzyme and the mixture was incubated at $50{ }^{\circ} \mathrm{C}$ for $5 \mathrm{~min}$. The reaction mixture was stopped by addition of $2 \mathrm{ml}$ of 3,5-dinitrosalicylic acid (DNSA) and the contents were boiled in a water bath for $10 \mathrm{~min}$. The colored solution was centrifuged at $8000 \times g$ for $5 \mathrm{~min}$ at 4 ${ }^{\circ} \mathrm{C}$. The absorption of supernatant was measured at 540 $\mathrm{nm}$ spectrophotometrically. The reducing sugar was estimated from standard curve of glucose (T60 UV-Visible) spectrophotometer, PG Instruments). One unit of Chitinase, defined as the amount of enzyme that liberates 1 $\mu \mathrm{mol}$ of glucose equivalent per min under the previous assay conditions and chitinase concentration, was calculated as follows.

$$
\begin{aligned}
& \text { Chitinase concentration }=\frac{\text { glucose concentration }(\mathrm{g} / \mathrm{l})}{0.00018} \mathrm{IU} / \mathrm{l} \\
& \begin{aligned}
\text { Enzyme activity }= & \text { Absorbance } \times \mathrm{DF} \times(1 / x)(1 / y) \\
& \times(1 / \mathrm{t}) \times(1 / \text { slope })
\end{aligned}
\end{aligned}
$$

Where DF is the dilution factor for enzyme; $x$ is the volume of enzyme used; $y$ is the volume of hydrolysate used

\begin{tabular}{|c|c|c|c|c|}
\hline Fungal species & Lipases & Phospholipases & Proteases & Chitinases \\
\hline Alternaria alternata & 10 & 0 & 25 & 0 \\
\hline A. tenuissima & 6 & 5 & 24 & 3 \\
\hline Aspergillus chevalieri & 6 & 6 & 0 & 2 \\
\hline A. flavus & 7 & 14 & 30 & 5 \\
\hline A. niger & 20 & 22 & 20 & 5 \\
\hline A. rugulosus & 15 & 4 & 24 & 2 \\
\hline A. sydowii & 15 & 0 & 30 & 2 \\
\hline A. terreus & 14 & 6 & 22 & 0 \\
\hline Botryotrichum atrogriseum & 30 & 4 & 20 & 5 \\
\hline Cochliobolus spicifer & 20 & 0 & 26 & 0 \\
\hline Epicoccum nigrum & 7 & 11 & 22 & 2 \\
\hline Fusarium chlamydosporum & 22 & 10 & 20 & 5 \\
\hline F. proliferatum & 15 & 9 & 20 & 3 \\
\hline F. semitectum & 6 & 10 & 29 & 5 \\
\hline F. solani & 10 & 4 & 22 & 5 \\
\hline F. subglutinans & 5 & 6 & 20 & 3 \\
\hline F. verticillioides & 15 & 6 & 25 & 2 \\
\hline Mucor racemosus & 0 & 22 & 20 & 0 \\
\hline Nigrospora oryzae & 10 & 10 & 18 & 5 \\
\hline Penicillium aurantiogriseum & 7 & 0 & 25 & 0 \\
\hline P. oxalicum & 5 & 4 & 26 & 4 \\
\hline Pochonia chlamydosporia var. catenulata & 10 & 20 & 20 & 5 \\
\hline Scopulariopsis brevicaulis & 12 & 17 & 50 & 5 \\
\hline Talaromyces pinophilum & 10 & 3 & 26 & 2 \\
\hline Toxicocladosporium irritans & 10 & 0 & 25 & 3 \\
\hline Verticillium sp. & 5 & 5 & 18 & 4 \\
\hline
\end{tabular}

Table 2 Enzymatic activities of isolated fungal species lipases, phospholipases, proteases, and chitinases expressed as depth of activity zone in $\mathrm{mm}$ 
for assay of reducing sugars; $t$ is the time of hydrolysis; slope is determined from a standard curve $\left(R^{2}\right)$ (Moubasher et al. 2016).

\section{Results}

Incidence of fungal species on indigenous and invasive insect species

Twenty-six fungal species were isolated, identified, and used for evaluating their enzymatic activities. Results presented in Table 1 showed that the fungal highest incidence was for Aspergillus niger $37.7 \%$ of total insects) followed by Alternaria tenuissima, Toxicocladosporium irritans, Fusarium proliferatum, Mucor racemosus Scopulariopsis brevicaulis, Fusarium chlamydosporum, Fusarium solani, and A. flavus (14.1-22.4\%). The remaining fungal species were less frequently isolated. The widest spectrum of fungal species was obtained from aphids (21 species) whereas the narrowest occurred on TLM (4 species). Invasive insects (RPW and PFF) produced 8 and 10 fungal species, respectively.

\section{Enzymatic activities of fungal strains Lipases}

Data in Table 2 and Fig. 1 indicated that all the tested strains, except Mucor racemosus were able to produce lipolytic enzymes. The most active fungi were $B$. atrogriseum, F.chlamydosporum, A.niger, C.spicifer, and F. proliferatum.

\section{Phospholipases}

The most active fungal strains in a descending order were A.niger $>M$. racemosus $>P$. chlamydosporia var. catenulata $>$ S.brevicaulis $>A$. flavus as shown in Table 2 and Fig. 2. Fungal strains belonging to Epicoccum, Fusarium, and Nigrospora exhibited an intermediate phospholipase activity.

\section{Proteases}

With the exception of A.chevalieri, the tested fungal strains proved to be active producers of proteolytic enzymes. The best producers were S. brevicaulis, A. flavus, A. sydowii, F. semitectum, and C.spicifer (Table 2 and Fig. 3 ).

\section{Chitinases}

A total of $21(80.8 \%)$ of the tested strains showed a positive activity (growth and clear zone) on the chitincontaining medium. Chitinolytic ability was generally low than other enzymatic activities (Table 2 and Fig. 4). The prominent fungal strains included $A$. flavus, A. niger, $B$. atrogriseum, F. semitectum, F. solani, N. oryzae, P.chlamydosporia var. catenulata, and S. brevicaulis (Table 3).

\section{Discussion}

In the present study, the common fungal species obtained from both indigenous and invasive insects were A.niger, A. tenuissima, T. irritans, F. proliferatum, M.racemosus, S. brevicaulis, $F$. chlamydosporum, $F$. solani, and A. flavus (14.1-37.7\% of total insects). Alternaria alternata occurred a low incidence on aphids and PFF (10.6\%). These results are more or less similar to previous reports from different countries. In Greece, Christias et al. (2001) isolated Alternaria alternata from dying and dead aphids. The fungus caused the most damage to the hemocytes but the adipose tissue and the gonads were also affected.

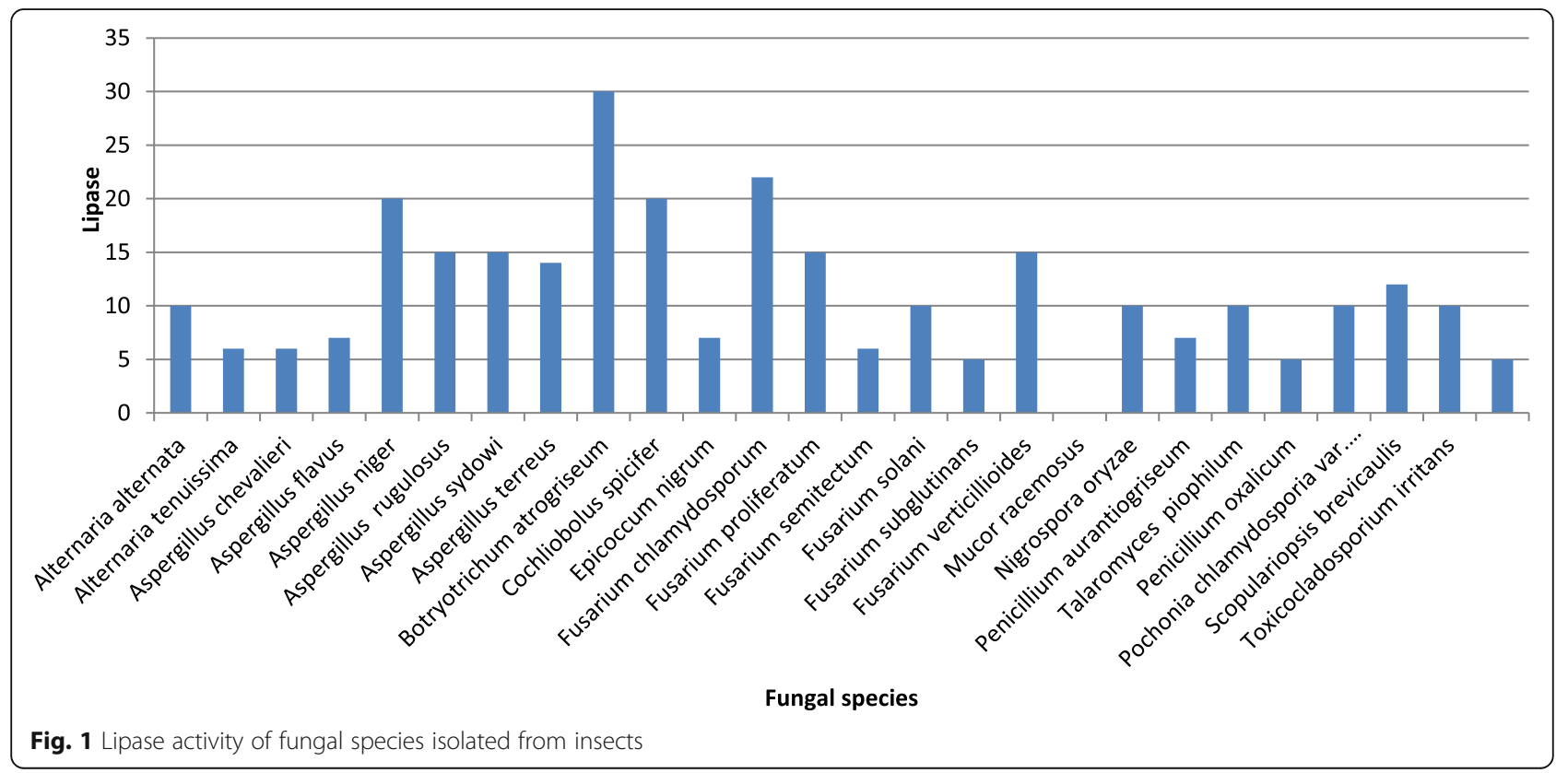




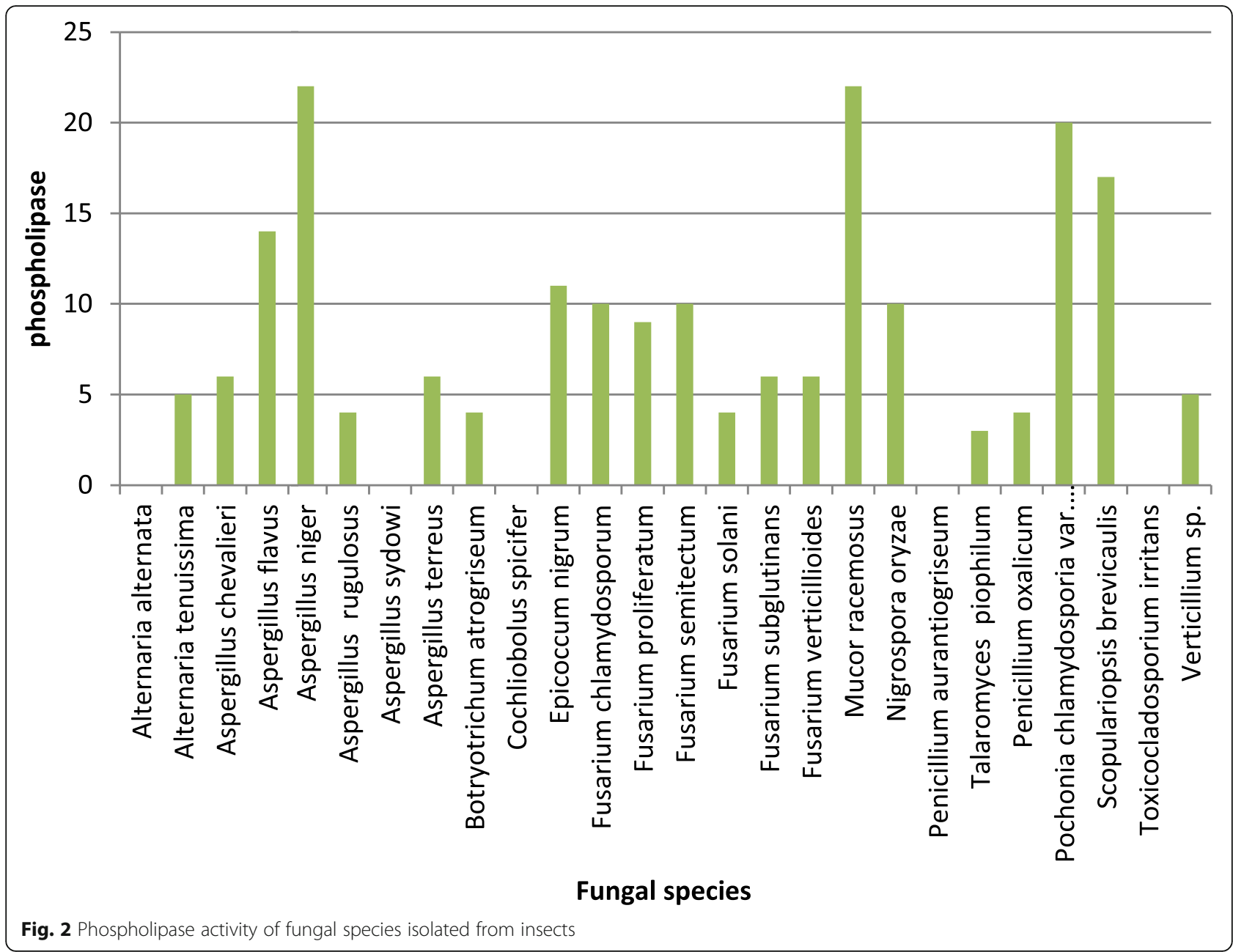

Six Fusarium species were isolated more frequently from aphids than from other insects. In India, Jayasimha et al. (2012) demonstrated that $F$. semitectum caused 79.90 and $64.40 \%$ mortality in nymphs and adults of okra aphid (A. gossypii), respectively, under laboratory and greenhouse conditions.

In Egypt, Abd El-Ghany et al. (2012) reported that $F$. chlamydosporum caused 58\% mortality in the larval stage of Galleria mellonella L., showing the possibility of applying this fungal species as a biocontrol agent. More recently, Abdel Galil et al. (2019) found that $F$. chlamydosporum, $F$. proliferatum, $F$. semitectum, $F$. solani, $F$. verticillioides, $P$. chlamydosporia var. catenulata, S. brevicaulis, and Verticillium sp. exhibited high virulences against wheat and bean aphids causing $60-100 \%$ mortality of the tested aphids.

Pathogenic activity of EPF depends on the ability of degrading insect's cuticle components by active secretion of hydrolyzing enzymes including lipases, phospholipases, proteases, and chitinases (Abd El-Ghany et al. 2012). In the present work, most of the tested fungal strains were able to produce lipolytic enzyme with the most active fungi being $B$. atrogriseum, $F$. chlamydosporum, A. niger, $C$. spicifer, and $F$. proliferatum. Lipases are responsible for the hydrolysis of ester bonds of lipoproteins, fats, and waxes found at the interior parts of the insect integument (Ali et al. 2009). Saleem (2008) tested the lipolytic activities of several fungal strains and found that $A$. alternata, A. flaves, A. sydowi, A. terreus, and C. spicifer were good producers of this enzyme.

Phospholipases are enzymes responsible for degrading phospholipids of insect's cuticle. Variation in phospholipases activity was observed among the 26 tested fungal strains. In the present study, the most active fungal strains were $A$. niger, $M$. racemosus, $P$. chlamydosporia var. catenulata, S. brevicaulis, and A. flavus. Fungal strains belonging to Epicoccum, Fusarium, and Nigrospora exhibited intermediate phospholipase activity. Ali et al. (2019) observed that clinical and environmental strains of A. flavus, $A$. niger, and $A$. terreus were active producers of esterase, phospholipase, and protease enzymes.

As shown from the obtained results, marked variations were observed in the proteolytic activities among the 26 


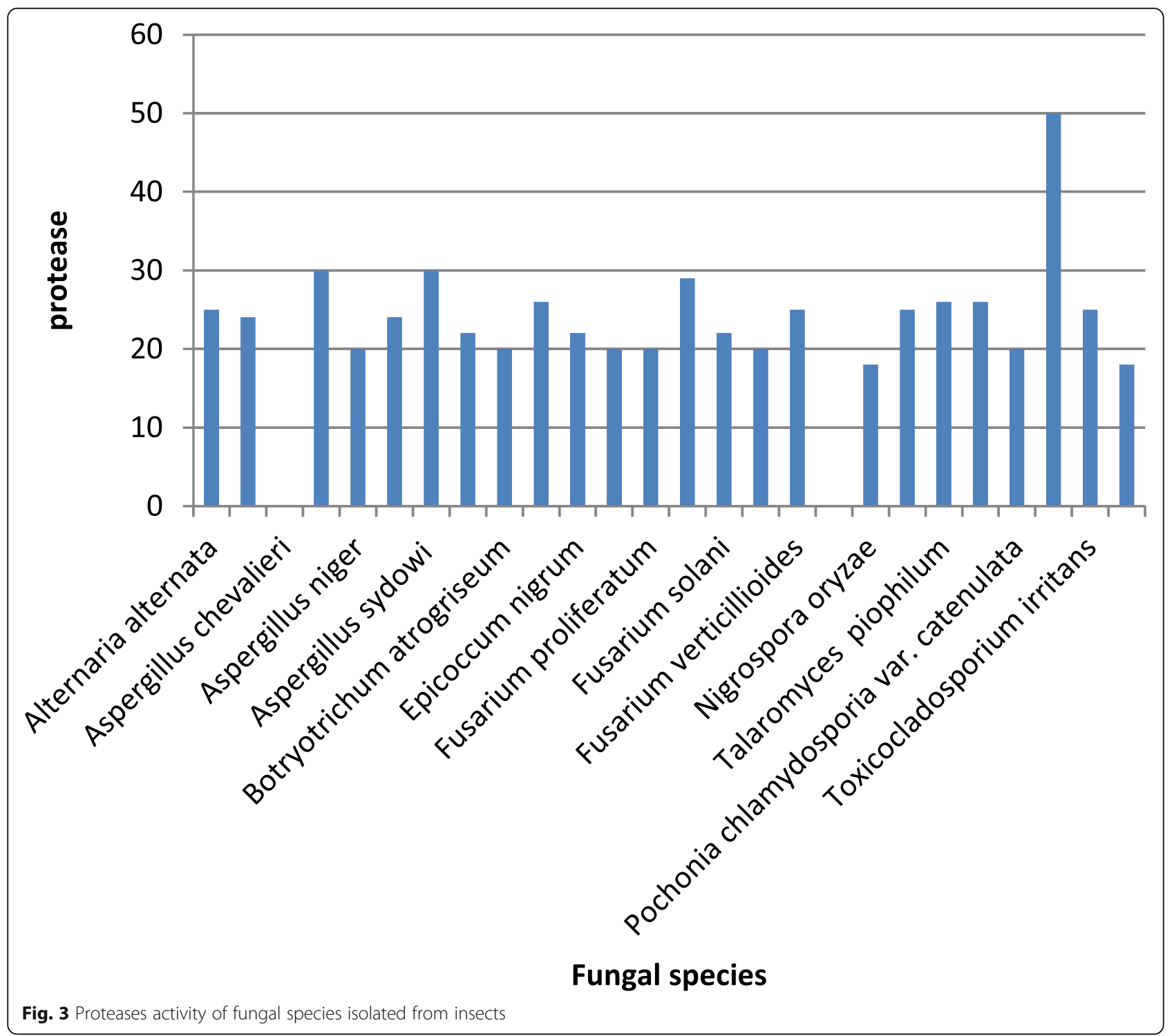

tested fungal strains. The best producers were $S$. brevicaulis, A. flavus, A. niger, A. sydowii, F. semitectum, and $C$. spicifer. Shimizuy et al. (1993) emphasized that extracellular proteases were even found in insect hemolymphs. Working with A. niger, Milala et al. (2016) reported that the maximum proteolytic activity was achieved after $48 \mathrm{~h}$ of incubation at $40^{\circ} \mathrm{C}$, using casine as a substrate.

Chitinolytic abilities of the fungi tested in the present study were generally lower than other enzymatic activities. The prominent fungal strains included $A$. flavus, $A$. niger, $B$. atrogriseum, $F$. semitectum, $F$. solani, $N$. oryzae, $P$. chlamydosporia var. catenulata, and S. brevicaulis. These enzymes act synergistically with chitinases in the solubilization of the insect cuticle. Establishing a relationship between the production of hydrolytic enzymes and the virulence of EPF may be useful in developing of screening methods for identifying new isolates with increased virulence and also for the development of bioproducts based on them (Montesinos-Matias et al. 2011). Chitinase was also produced by a halophilic strain of A. flavus isolated from Gulf of Suez, Egypt, with activity 620.54 U/l (Beltagy et al. 2018). Therefore, they suggested that the insecticidal effects of EPF could be directly linked with the activity of cuticle hydrolytic enzymes. Enzyme secretion by EPF may be involved in the degradation of cuticular polymers during pathogenesis, assisting in the penetration of the insect exoskeleton and providing nutrients for fungal growth. These enzymes can act synergistically, helping fungi to control insect pests and pathogens that attack productive crops, and offer potential economic benefit to agribusiness. 


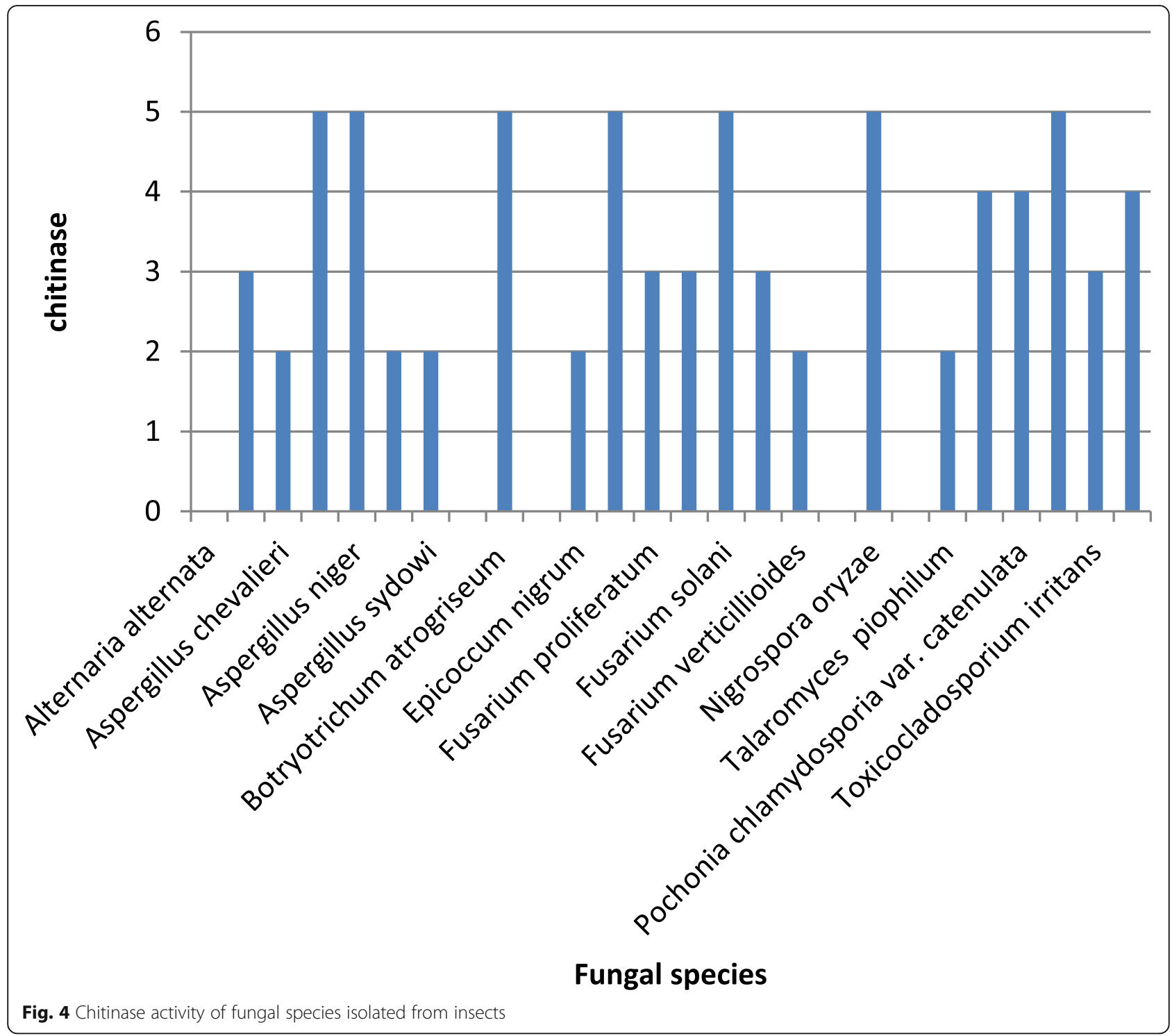

\section{Conclusion}

Aspergillus niger, B. atrogriseum, C. spicifer, F. chlamydosporum, and $F$. proliferatum were being the most active fungi for producing lipolytic enzymes. Aspergillus

Table 3 Concentration of chitinase produced by fungi isolated from insects

\begin{tabular}{|c|c|c|c|}
\hline Fungal species & $\begin{array}{l}\text { Glucose } \\
(\mathrm{g} / \mathrm{l})\end{array}$ & $\begin{array}{l}\text { Chitinase } \\
\text { conc. (IU/ml) }\end{array}$ & $\begin{array}{l}\text { Chitinase activity } \\
\text { (IU/ml/min) }\end{array}$ \\
\hline Aspergillus niger & 1.159 & 6.44 & 0.041 \\
\hline Fusarium semitectum & 0.726 & 4.032 & 0.025 \\
\hline F. solani & 0.980 & 5.443 & 0.034 \\
\hline $\begin{array}{l}\text { Pochonia chlamydosporia } \\
\text { var. catenulata }\end{array}$ & 1.022 & 5.677 & 0.036 \\
\hline $\begin{array}{l}\text { Scopulariopsis } \\
\text { brevicaulis }\end{array}$ & 0.626 & 3.478 & 0.022 \\
\hline
\end{tabular}

flavus, A. niger, $M$. racemosus, $P$. chlamydosporia var. catenulata, and S. brevicaulis were the highest producers of phospholipase. Aspergillus chevalieri and M. racemosus cannot produce protolytic enzymes. The best proteolytic strain was $S$. brevicaulis followed by A. flavus, $A$. sydowii, and $F$. semitectum. The chitinolytic ability of the fungal strains was generally weak and the relatively active species belonged to $A$. flavus, $A$. niger, B. atrogriseum, F. chlamydosporum, F. solani, S. brevicaulis, and Nigrospora oryzae.

\section{Abbreviations}

EPF: Entomopathogenic fungi; TLM: Tomato leaf miner; RPW: Red palm weevil; PFF: Peach fruit fly; A. niger: Aspergillus niger; F. proliferatum: Fusarium proliferatum; A. flavus: Aspergillus flavus; A. chevalieri: Aspergillus chevalieri; M. racemosus: Mucor racemosus; A. sydowii: Aspergillus sydowii; $F$.

semitectum: Fusarium semitectum; B. atrogriseum: Botryotrichum atrogriseum; $F$. chlamydosporum: Fusarium chlamydosporum; F. solani: Fusarium solani; S.

brevicaulis: Scopulariopsis brevicaulis 


\section{Acknowledgements}

First of all, prayerful thanks to God for the power, endurance, and everything I have. I wish to express my sincere gratitude and appreciation to my supervisors Prof. Dr. Ahmed M. Moharram, Professors of Microbiology, Botany Department, Faculty of Science, Assiut University and Prof. Dr. Farouk A. Abdel-Galil, Professors of Entomology, Plant Protection Department, Faculty of Agriculture, Assiut University, they took time out from their busy lives to help me and guided me. They did so far no financial gain being motivated primarily by a desire to make that present works the best.

\section{Authors' contributions}

WMMH, original writing, reviewing the article, performed the laboratory examination, and collected the data. AMM and FAA review the manuscript. All authors read and approved the final manuscript.

\section{Funding}

Not applicable

Availability of data and materials

Not applicable

\section{Declarations}

Ethics approval and consent to participate

Not applicable

\section{Consent for publication}

Not applicable.

\section{Competing interests}

The authors declare that they have no competing interests.

\section{Author details}

'Department of Botany and Microbiology, Faculty of Science, Assiut University, Assiut, Egypt. ${ }^{2}$ Department of Plant Protections, Faculty of Agriculture, Assiut University, Assiut, Egypt.

Received: 7 February 2021 Accepted: 3 March 2021

Published online: 16 March 2021

\section{References}

Abd El-Ghany TM, El-Sheikh HH, Abd El-Rahman GA, Abd El-Nasser AM (2012) Biodiversity of entomopathogenic fungi in new cultivated soil with their using to control of Galleria mellonella. Int J Curr Res Rev 4(24):17-31

Abdel Galil FA, Moharram AM, Mahmoud MA, Hafez WMM (2019) Biocontrol of bean and wheat aphids by fungi isolated from indigenous and invasive insects collected from different locations in Minia Governorate, Egypt. Egypt Acad J Biol Sci F Toxicol Pest Control 11(3):79-90

Abelardo G, Vicente R, Enrique M, Gervasio T, Maria D (2010) Development of a bioacoustic sensor for the early detection of red palm weevil (Rhynchophorus ferrugineus Olivier). Crop Prot 29(7):671-676

Aboul-Ela RG, Hashem EG, Mohamed SMA (1998) Bactrocera pallidus(Perkins and may) (Diptera: Tephritidae), a new record in Egypt. J Egypt Ger Soc Zool 27(E):221-229

Ali MIA, Behiry IK, Khalil NM, Marghany FA (2019) Hydrolytic enzymes as probable virulence factors For Aspergillus ochraceus Fm90 in Aspergillosis. Egypt J Bot 59(2):425-438

Ali S, Huang Z, Ren SX (2009) Production and extraction of extracellular lipase from the Entomopathogenic Fungus Isaria fumosroseus (Cordycipitaceae: Hypocreales). Biocontrol Sci Technol 19(1):81-89. https://doi.org/10.1080/ 09583150802588524

Beltagy EA, Rawway M, Abdul-Raouf UM, Elshenawy MA, Kelany MS (2018) Purification and characterization of theromohalophilic chitinase producing by halophilic Aspergillus flavus isolated from Suez Gulf. Egypt J Aquat Res 44(3): 227-232. https://doi.org/10.1016/j.ejar.2018.08.002

Bensch K, Braun U, Groenewald JZ, Crous PW (2012) The genus Cladosporium. Stud Mycol 72(1):1-401. https://doi.org/10.3114/sim0003

Christias CH, Hatzipapas P, Dara A, KaliafAS A, Chrysanthis G (2001) Alternaria alternata, a new pathotype pathogenic to aphids. BioControl 46(1):105-124. https://doi.org/10.1023/A:1009930112152
Domsch KH, Gams W and Anderson T (2007) Compendium of soil. Fungi. 2nd Ed. IHW VerlagEching, Germany. 672 pp

El-Mergawy RAAM, Al-Ajlan AM (2011) Red palm weevil, Rhyncho-phorus ferrugineus (Olivier): economic importance, biology, biogeography and integrated pest management. J Agric Sci Technol A 1:1-23 Earlier title: Journal of Agricultural Science and Technology, ISSN 1939-1250

El-Minshawy AM, Al-Eryan MA and Awad Al (1999). Biological and morphological studies on the guava fruit fly, Bactrocera zonata (Diptera: Tephritidae) found recently in Egypt. 8th Na. Con. of pests and Dis. of Veg. and fruits in Ismailia, Egypt. 9-10 November. pp.71-81

Ismail, MA, Abdel-Hafez, SII, Hussein, NA and Abdel-Hameed, NA (2015) "Contributions to the genus Fusarium in Egypt with dichotomous keys for identification of species". Szkółkarska 88B, 62-002 Suchy Las, Poland, 175 pp

Jayasimha GT, Rachana RR, Rajkumar VB, Manjunatha M (2012) Evaluation of fungal pathogen, Fusarium semitectum Berk and Ravenel against okra aphid, Aphis gossypii Glover under laboratory and green house conditions. Pest Manage Hortic Ecosyst 18(2):139-142

Jenin GA, Babu MM, Murugan M, Murugan T (2016) Isolation and identification of chitinase producing native fungi from Saltpan of Puthalam, Kanyakumari District, Tamil Nadu, India. J Appl Biol Biotechnol 4(3):1-5

Jha SC and Modi (2017) Comparative analysis of chitinase activity by four different assay from soil born Actinomycetes. 4th International Conference on Multidisciplinary Research \& Practice (4ICMRP) Gujarat University, (India), 185-190

Kaur G, Padmaja V (2009) Relationships among activities of extracellular enzyme production and virulence against Helicoverpa armigera in Beauveria bassiana. J Basic Microbiol 49(3):264-274. https://doi.org/10.1002/jobm.200800156

Milala MA, Jatau IA, Abdulrahman AA (2016) Production and optimization of protease from Aspergillus niger and Bacillus subtilis using response surface methodology. J Biotechnol Biochem (IOSR-JBB) 2:1-7

Montesinos-Matías R, Viniegra-González G, Alatorre-Rosas R, Loera O (2011) Relationship between virulence and enzymatic profiles in the cuticle of Tenebrio molitor by 2-deoxy-d-glucose-resistant mutants of Beauveria bassiana (Bals.) Vuill. World J Microbiol Biotechnol 27(9):2095-2102. https://doi.org/10.1007/s11274-011-0672-z

Moubasher AH, Ismail MA, Mohamed RA, Al-Bedak OA (2016) Xylanase and cellulase production under extreme conditions in submerged fermentation by some fungi isolated from hypersaline, alkaline lakes of Wadi-El-Natrun, Egypt. J Basic Appl Mycol 7:19-32

Paterson RRM, Bridge PD (1994) Biochemical techniques for filamentous fungi. International Mycological Institute CAB International Survey, Wallingford P. 21 UK

Saleem A (2008) Effect of some food preservatives on the lipolytic activity of beef luncheon fungi. Mycobiology 36(3):167-172. https://doi.org/10.4489/MYCO.2 008.36.3.167

Samaranayake YH, Dassanayake RS, Jayatilake JAMS, Cheung BPK, Yau JYY, Yeung KWS, Samaranayake LP (2005) Phospholipase B enzyme expression is not associated with other virulence attributes in Candida albicans isolates from patients with human immunodeficiency virus infection. J Med Microbiol 54(6):583-593. https://doi.org/10.1099/jmm.0.45762-0

Sánchez-Pérez R, Del Cueto J, Dicenta F, Martínez-Gómez P (2014) Recent advancements to study flowering time in almond and other Prunus species. Front Plant Sci 5:334-334

Shimizuy S, Tsuchitan I, Matusumoto T (1993) Production of an extracellular protease by Beauveria bassiana in the haemolymph of the silkworm, Bombyx mori. Lett Appl Microbiol 16(6):291-294. https://doi.org/10.1111/j.1472-765X.1993.tb00360.X

Ulman V, Blasins G (1974) A simple medium for the detection of different lipolytic activity of microorganisms. Zintrabl. Bakteriol. Hyg. II.Abt. A. 229:264-267

Wang C, Typas MA, Butt TM (2002) Detection and characterization of Pr1 virulent gene deficiencies in the insect pathogenic fungus Metarhizium anisopliae. FEMS Microbiol Lett 213(2):251-255. https:/doi.org/10.1111/j.1574-6968.2002.tb11314.x

\section{Publisher's Note}

Springer Nature remains neutral with regard to jurisdictional claims in published maps and institutional affiliations. 